\title{
A mathematical model to estimate the volume of grey water of pesticide mixtures
}

\author{
Lourival C. Paraíba, Ricardo A. A. Pazianotto, Alfredo J. B. Luiz, \\ Aline H. N. Maia, Cláudio M. Jonsson \\ Embrapa Meio Ambiente \\ 13820-000, Cx.P. 69, Jaguariúna, SP. \\ E-mail: lourival.paraiba@embrapa.br
}

\begin{abstract}
We propose a model to estimate the grey water footprint of crops by calculating the volume of water necessary to dilute pesticide mixtures reaching freshwaters. The model requires short-term toxicity data from aquatic organisms based on EC50 values, soil pesticide half-life and soil sorption coefficient values, and does not require maximum concentration limit acceptable in water. The lixiviation rate and runoff rate of each pesticide was estimated by attenuation factor and by Soilfug model, respectively. The usefulness of the proposed model was illustrated by estimating the volume of grey water required to dilute the seventeen most widely used herbicides in the sugarcane crops in Brazil. These results establish the ranking position of each herbicide in the composition of the grey water footprint of mixture of herbicides. The rank of each herbicide could be used to create a label to be placed on the package of the pesticide, thus informing farmers about the volume of grey water per hectare due to the use of this herbicide.
\end{abstract}

Key words: water footprint, pesticide management; sugarcane; herbicide;

\section{Introduction}

The water footprint (WF) is an indicator of freshwater use that considers the indirect as well as the direct water use of a consumer or producer [1]. The concept of water footprint was first introduced and refined by [15], based on the virtual water concept of [4, 5], who proposed a numerical indicator to express the water volume used in the entire production chain of a certain agricultural product. Grey water is defined as the volume of water required to assimilate the load of pollutants (pesticides and fertilizers) based on water quality standards [2]. Thus, the grey water footprint is the amount of water needed to get the concentration down to an acceptable level. The term 'grey water footprint' was for the first time introduced by [1] and defined as the pollutant load divided by the maximum acceptable concentration in the receiving water body. A bit later, it was recognized that the grey water footprint is better calculated as the pollutant load divided by the difference between the maximum acceptable and the natural background concentration [2].

Several studies have calculated the water footprint of a wide variety of agricultural products such as cotton [10], rice [9], wheat [17], mango fruit [21], tea and coffee [8], meat and derivates [22], olives and olive oil [23] and fresh tomatoes [18]. Most of these studies have estimated the volume of grey water for fertilizers, especially nitrogen and phosphorus, ignoring the potential contamination by applied pesticides, resulting in an underestimation of the volume of grey water. Generally, several pesticides are applied to a crop. As a consequence, a set of pesticides may be detected in a same water body, characterizing a water contamination by pesticide mixtures with different concentrations, occurring simultaneously in a particular water body $[14,24]$. The quantification of grey water of an agricultural product, based on produced grey water from a pesticide mixture is the volume of freshwater required to dilute the concentration of the mixture in freshwater at a level which would lead to the protection of aquatic organisms against the toxic effects of each pesticide in the mixture. The grey water volume can be determined through the pesticide physical-chemical characteristics, pesticide rates applied (dose), and the lowest EC50 value from the more susceptible aquatic organism. Thus, grey water volume based on pesticide mixture approach does not depend upon threshold 
concentrations for contaminants established by governmental agencies, but upon effective concentrations for key aquatic organisms, ecotoxicological data most often available.

The aim of this paper is to propose a model to estimate the volume of grey water (grey water footprint) for an agricultural product based on the toxicity of each pesticide used in a particular crop system. In order to demonstrate the utility of our model, using ecotoxicology of pesticide mixtures, we present a study for a sugarcane cropping system in Brazil destined to sugar and ethanol production, using a set of herbicides.

\section{Model development}

The volume of grey water by crop yield produced, $V G W_{Y}\left(\mathrm{~m}^{3} \operatorname{ton}^{-1}\right)$, is given by $V G W_{Y}=\frac{V G W_{P M}}{Y}$ (Eq. 1), where $V G W_{P M}\left(\mathrm{~m}^{3} \mathrm{yr}^{-1}\right)$ is the volume of grey water of the pesticide mixture of pesticides used in the crop production and $Y$ (ton $\mathrm{yr}^{-1}$ ) is the total annual crop production [17]. The volume of grey water of the pesticide mixture, $V G W_{P M}$, was calculated through the application of the Concentration Addition model [7, 16, 13] given by $\sum_{i=1}^{n} \frac{P E C_{i}}{P N E C_{i}}=1$ (Eq. 2), where $n$ is the number of pesticides used in the crop system, PEC (kg $\left.\mathrm{m}^{-3}\right)$ is the Predicted Environmental Concentration in water of the pesticide and PNEC $\left(\mathrm{kg} \mathrm{m}^{-3}\right)$ is the Predicted No Effect Concentration of pesticide in water [13]. The PNEC values were determined based on the observation of the pesticide acute toxicity effect, EC50 (mg L $\left.{ }^{-1}\right)$ values on the organism population, indicator of water quality, and representative of reference trophic levels of the aquatic ecosystem (algae, daphnids and fish). A security factor nominated assessment factor, $A_{S F}$ is applied to the lowest EC50 value derived from the more susceptible organism. The assessment factor (security or uncertainty) is an adjustment number range from 1-1000, normally used to extrapolate undesirable toxic effects from acute toxic effects experimentally determined on indicator species. The values of the assessment factors $\left(A_{S F}\right)$ depend on the extent and nature of the toxicity data. Thus, the predicted environmental concentration of pesticide in freshwater, PEC $\left(\mathrm{kg} \mathrm{m}^{-3}\right)$, was estimated by equation $P E C=\frac{M}{V G W_{P M}}($ Eq. 3$)$, where $M(\mathrm{~kg})$ is the pesticide mass. Assuming that each pesticide has a linear sorption and a first order kinetic degradation in soil, the pesticide mass in freshwater is given by $M=\alpha A_{C} A_{D}+(1-\alpha) A_{C} A_{D} A_{F}$ (Eq. 4), where $A_{C}$ (ha) is the cultivated area by year, $A_{D}\left(\mathrm{~kg} \mathrm{ha}^{-1}\right)$ is the pesticide dose, $0 \leq A_{F} \leq 1$ (dimensionless) is the pesticide attenuation factor from soil surface to groundwater, and $0 \leq \alpha \leq 1$ ( $\mathrm{kg}$ year $\mathrm{kg}^{-1}$ year ${ }^{-1}$ ) is the pesticide dose fraction that reaches the freshwater due to runoff. In Eq. (4), the pesticide attenuation factor $\left(A_{F}\right)$ is a measure related to pesticide mass emission to groundwater which was first developed as a screening index to order pesticides according to its pollutant potential. The $A_{F}$ expression is obtained from the analytic solution of a simplified convection-dispersion equation of pesticide in soil solution. Under field capacity, this solution assumes the pesticide first-order degradation rate, omitting soil water flow, hydrodynamic dispersion and molecular diffusion [26]. The pesticide attenuation factor is calculated by $A_{F}=\exp \left(\frac{-k z R_{F} \theta_{f c}}{J_{W}}\right)$ (Eq. 5), where $z$ (m) is the soil depth, $k$ (day $\left.{ }^{-1}\right)$ is the soil pesticide degradation rate estimated by $k=\ln (2) / t_{1 / 2}$, where $t_{1 / 2}$ (day) is the pesticide half-life in soil, $R_{F}$ (dimensionless) is the pesticide retardation factor, $\theta_{f c}\left(\mathrm{~L} \mathrm{~L}^{-1}\right)$ is the soil volumetric water content at field capacity, and $J_{W}\left(\mathrm{~m} \mathrm{day}^{-1}\right)$ is the water daily net recharge of the soil area. The retardation factor is a number that represents the 
delay of the pesticide leaching with regard to the water flow in soil. This leaching delay is due to both pesticide sorption and pesticide aqueous diffusion in soil. The effect of the retardation factor on pesticide leaching can be noticed graphically in the breakthrough curve when solving the convection-dispersion equation of pesticide in soil solution. The graph of breakthrough curve represents the relationship between the relative concentration and time evolution concentration $[19,26]$. In Eq. [5], the retardation factor is given by $R_{F}=1+\frac{\rho_{s} f_{o c} k_{o c}}{\theta_{f c}}$ (Eq. 6), where $\rho_{s}\left(\mathrm{~kg} \mathrm{~L}^{-1}\right)$ is the total soil density, $k_{o c}\left(\mathrm{~L} \mathrm{~kg}^{-1}\right)$ is the pesticide soil organic carbon partition coefficient (pesticide soil sorption) and $f_{o c}\left(\mathrm{~L} \mathrm{~L} \mathrm{~L}^{-1}\right)$ is the soil volumetric organic carbon content [20]. In Eq. (4), the factor $\alpha$ stands for the pesticide runoff fraction, defined as the fraction of applied pesticide reaching surface water by runoff. The SoilFug model [12] was utilized to estimate the dimensionless factor $\alpha$.

Replacing Eq. (3) and (4) in Eq. (2) we obtain the following equalities $\sum_{i=1}^{n}\left(\frac{\frac{\alpha^{i} A_{C}^{i} A_{D}^{i}+(1-\alpha) A_{C}^{i} A_{D}^{i} A_{F}^{i}}{V G W_{P M}}}{P N E C_{i}}\right)=1 \Rightarrow \frac{1}{V G W_{P M}} \sum_{i=1}^{n}\left(\frac{\alpha^{i} A_{C}^{i} A_{D}^{i}+(1-\alpha) A_{C}^{i} A_{D}^{i} A_{F}^{i}}{P N E C_{i}}\right)=1$ (Eq.7).

Consequently, the volume of grey water of the pesticide mixture, $V G W_{P M}\left(\mathrm{~m}^{3}\right)$, can be

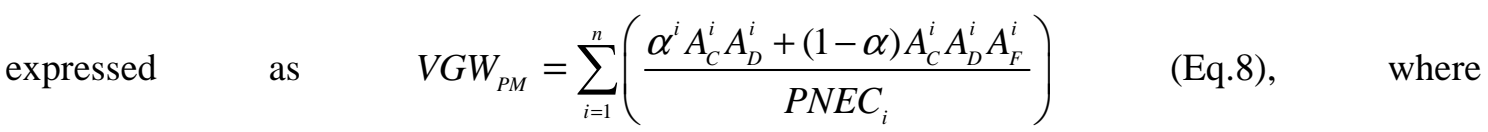
$P N E C_{i}=\frac{10^{-3}}{A_{S F}} \min \left\{E C 50_{\{a \mid \mathrm{lg} a e, d a p h n i d s, f \text { fish }\}}^{i}\right\}$ [13]. From Eq. (8), the volume of grey water of each pesticide in the mixture, $V G W_{i}\left(\mathrm{~m}^{3}\right)$, is given by $V G W_{i}=\frac{\alpha^{i} A_{C}^{i} A_{D}^{i}+\left(1-\alpha^{i}\right) A_{C}^{i} A_{D}^{i} A_{F}^{i}}{P N E C_{i}}$ (Eq. 9). In addition, we propose a new way to express the relative position of each individual pesticide in the mixture, referred to as pesticide rank. Considering only one hectare, the volume of grey water of each pesticide, $V G W_{i}^{h a}\left(\mathrm{~m}^{3} \mathrm{ha}^{-1}\right)$, was estimate dividing the $V G W_{i}\left(\mathrm{~m}^{3}\right.$, Eq. 9) by $A_{C}^{i}$ (ha), that is, $V G W_{i}^{h a}=V G W_{i} / A_{C}^{i}$. The pesticide rank, $r_{i}$, is calculated as the logarithm of $V G W_{i}^{h a}$ given by $r_{i}=\log \left(V G W_{i}^{h a}\right)$ (Eq. 10).

\section{Numerical simulation: input data}

The model given by Eq. [8] was used to estimate the water volume of herbicide used in Brazilian sugarcane crops in sugar and ethanol production. Some of the main herbicides registered in Brazil for sugarcane cropping are listed in Table 1, as well as the information on their recommended dose $\left(\mathrm{kg} \mathrm{ha}^{-1}\right)$, area of application (ha), toxicity $\left(\mathrm{mg} \mathrm{L}^{-1}\right)$ on algae, daphnids and fish data (EC50 values), soil organic carbon partition coefficient $\left(\mathrm{L} \mathrm{kg}^{-1}\right)$, and half-life (day) in soil. For the calculus of the retardation and attenuation factors (Eqs. 5-6) was assumed a homogeneous soil with $2.0 \mathrm{~m}$ depth; total density of $1.5 \mathrm{~kg} \mathrm{~L}^{-1}$; soil organic carbon volumetric fraction, $f_{o c}$, of 0.003 ; water volumetric fraction at field capacity, $\theta_{f c}$, of 0.25 ; and a net recharge rate, $J_{W}$, of $9.18 \times 10^{-4} \mathrm{~m} \mathrm{day}^{-1}$ for soils cultivated with sugarcane [25]. The assessment factor, in the calculations of $P N E C$, is arbitrarily chosen between 10 and 1000, in this work we assume the value of 100 (EEC, 2003). The Soilfug model, using daily rainfall data for the period of 2009/2011 of the Ribeirão dos Marins Watershed, São Paulo State, registered by the Agrometeorology Integrated Information Center of the Agronomic Institute of Campinas, was used to determinate the average values of the runoff rate $\alpha\left(\mathrm{kg} \mathrm{year} \mathrm{kg}^{-1}\right.$ year $\left.^{-1}\right)$, for each herbicide in Table 1. 
There is no official data of pesticides use in Brazil per year and crop type, nor is there information about total area of application or total volume used. Only as an example to permit using the proposed method in Brazilian sugarcane crop we assumed that the total area cultivated in 2011/2012 received some herbicide. To find an estimate of area for each herbicide we adopted the same percentage of area per herbicide found by [6] we extrapolate the data for all Brazilian area (Table 1).

Table 1. Data on application (recommended dose and sprayed area), toxicity to aquatic organisms (algae, daphnids and fishes) and pesticide fate coefficients in soil (degradation and sorption) for the studied herbicides in a hypothetical Brazilian sugarcane production system.

\begin{tabular}{cccccccc}
\hline \multirow{2}{*}{ herbicides } & \multirow{2}{*}{$\begin{array}{c}\text { pesticide's } \\
\text { dose }\end{array}$} & crop area & \multicolumn{3}{c}{ toxicity* $(E C 50)$} & \multicolumn{3}{c}{$\begin{array}{c}\text { pesticide fate } \\
\text { coefficients** }\end{array}$} \\
\cline { 3 - 8 } & & & algae & daphnids & fish & $\begin{array}{c}\text { half-life } \\
\text { sorption }\end{array}$ \\
& $\left(A_{D}\right)$ & $\left(A_{C}\right)$ & & & & $\left(t_{1 / 2}\right)$ & $\left(k_{o c}\right)$ \\
$\left(\mathrm{kg} \mathrm{ha}^{-1}\right)$ & $(\mathrm{ha})$ & & $\left(\mathrm{mg} \mathrm{L}^{-1}\right)$ & & $(\mathrm{day})$ & $\left(\mathrm{L} \mathrm{kg}^{-1}\right)$ \\
\hline ametryn & 2.23 & $1.88 \times 10^{6}$ & 0.0037 & 28.0 & 1.0 & 60 & 300 \\
amicarbazone & 1.00 & $3.36 \times 10^{4}$ & 0.084 & 0.252 & 13.0 & 54 & 37 \\
carfentrazone & 0.04 & $3.36 \times 10^{4}$ & 0.0127 & 9.8 & 0.0164 & 3 & 750 \\
clomazone & 1.00 & $1.52 \times 10^{6}$ & 3.5 & 5.2 & 19.0 & 24 & 300 \\
diuron & 1.83 & $1.00 \times 10^{6}$ & 0.0024 & 0.113 & 0.0618 & 90 & 480 \\
glyphosate & 1.62 & $9.22 \times 10^{5}$ & 2.2 & 3.0 & 1.3 & 47 & 24000 \\
hexazinone & 0.29 & $8.51 \times 10^{5}$ & 0.0068 & 33.1 & 100.0 & 90 & 54 \\
imazapic & 0.22 & $6.69 \times 10^{5}$ & 0.0523 & 100.0 & 98.7 & 90 & 1 \\
imazapyr & 0.33 & $5.02 \times 10^{5}$ & 12.2 & 100.0 & 100.0 & 90 & 100 \\
isoxaflutole & 0.16 & $3.03 \times 10^{5}$ & 0.14 & 1.5 & 1.7 & 100 & 400 \\
metribuzin & 1.58 & $2.78 \times 10^{5}$ & 0.0081 & 4.18 & 42.0 & 40 & 60 \\
oxyfluorfen & 2.00 & $1.32 \times 10^{4}$ & 0.0003 & 0.08 & 0.17 & 35 & 5000 \\
pendimethalin & 1.38 & $2.53 \times 10^{5}$ & 0.0054 & 0.28 & 138.0 & 90 & 5000 \\
sulfentrazone & 0.70 & $7.08 \times 10^{4}$ & 0.031 & 60.4 & 93.8 & 540 & 887 \\
tebuthiuron & 1.00 & $6.06 \times 10^{4}$ & 0.05 & 297.0 & 106.0 & 360 & 80 \\
trifloxysulfuron & 0.04 & $5.31 \times 10^{4}$ & 0.0065 & 108.0 & 103.0 & 78 & 1 \\
trifluralina & 0.80 & $3.32 \times 10^{4}$ & 0.339 & 0.56 & 0.0007 & 60 & 8000 \\
\hline
\end{tabular}

Sources: *http://www.ipmcenters.org/Ecotox/index.cfm; **Hornsby et al. (1996)

\section{Results and discussions}

Table 2 shows average values of the runoff rate $0 \leq \alpha^{i} \leq 1$ estimated by the Soilfug model, for each herbicide in Table 1. It also shows the values of grey water of each one of the herbicides $\left(V G W_{i}\right.$, Eq. 9). The rank $r_{i}$ of the herbicides in the mixture, Eq. [10], is given in Table 2. The herbicides in the hypothetical mixture were ranked according to the method summarized in Eq. [10], based in the relative contribution of each herbicide to the sugarcane grey water volume, related to their potential hazards to aquatic life. The total volume of grey water of herbicide mixtures, was estimated in $V G W_{P M}=2.36 \times 10^{12} \mathrm{~m}^{3} \mathrm{yr}^{-1}$ (Eq. 8).

The rank of each herbicide could be used to create a label to be placed on the package of the pesticide, thus informing farmers about the volume of grey water per hectare due to the use of this herbicide. According to [11], the sugarcane Brazilian production, harvest 2011/2012, reached $5.96 \times 10^{8}$ tons on a cultivated area of $8.4 \times 10^{6}$ ha. From these production values and cultivated area, and from the grey water volume of herbicides of $2.36 \times 10^{12} \mathrm{~m}^{3} \mathrm{yr}^{-1}$ (Eq. 8) it is possible to estimate the volume of grey water per volume of produced sugarcane in $3,966 \mathrm{~m}^{3}$ ton $^{-1}$ (cubic meters of grey water per ton of sugarcane) in the Brazilian harvest of 2011/2012. 
Table 2. Pesticide-specific estimates compounding grey water for the herbicide mixture in a hypothetical sugarcane production system over $8.4 \times 10^{6}$ ha: runoff rate $\alpha^{i}$; volume of grey water $\left(V G W_{i}\right)$; volume of grey water per hectare $\left(V G W_{i}^{h a}\right)$; and rank $\left(r_{i}\right)$, as $\log \left(V G W_{i}^{h a}\right)$.

\begin{tabular}{ccccc}
\hline herbicides & $\begin{array}{c}\alpha^{i} \\
\left(\mathrm{~kg} \mathrm{year} \mathrm{kg}^{-1} \text { year }^{-1}\right)\end{array}$ & $\begin{array}{c}V G W_{i} \\
\left(\mathrm{~m}^{3}\right)\end{array}$ & $\begin{array}{c}V G W_{i}^{h a} \\
\left(\mathrm{~m}^{3} \mathrm{ha}^{-1}\right)\end{array}$ & $r_{i}$ \\
\hline $\begin{array}{c}\text { ametryn } \\
\text { amicarbazone }\end{array}$ & 0.0110 & $1.29 \times 10^{12}$ & $6.87 \times 10^{5}$ & 5.8 \\
carfentrazone & 0.0470 & $1.88 \times 10^{9}$ & $5.59 \times 10^{4}$ & 4.7 \\
clomazone & 0.0000 & $4.20 \times 10^{6}$ & $1.25 \times 10^{2}$ & 2.1 \\
diuron & 0.0070 & $2.91 \times 10^{8}$ & $1.91 \times 10^{2}$ & 2.3 \\
glyphosate & 0.0080 & $6.07 \times 10^{11}$ & $6.05 \times 10^{5}$ & 5.8 \\
hexazinone & 0.0001 & $1.56 \times 10^{7}$ & $1.69 \times 10$ & 1.2 \\
imazapic & 0.0450 & $1.64 \times 10^{11}$ & $1.93 \times 10^{5}$ & 5.3 \\
imazapyr & 0.1130 & $9.58 \times 10^{10}$ & $1.43 \times 10^{5}$ & 5.2 \\
isoxaflutole & 0.0300 & $4.07 \times 10^{7}$ & $8.11 \times 10$ & 1.9 \\
metribuzin & 0.0100 & $3.29 \times 10^{8}$ & $1.09 \times 10^{3}$ & 3.0 \\
oxyfluorfen & 0.0310 & $1.69 \times 10^{11}$ & $6.09 \times 10^{5}$ & 5.8 \\
pendimethalin & 0.0010 & $5.12 \times 10^{9}$ & $3.86 \times 10^{5}$ & 5.6 \\
sulfentrazone & 0.0010 & $5.29 \times 10^{9}$ & $2.09 \times 10^{4}$ & 4.3 \\
tebuthiuron & 0.0060 & $9.33 \times 10^{8}$ & $1.32 \times 10^{4}$ & 4.1 \\
trifloxysulfuron & 0.0440 & $1.21 \times 10^{10}$ & $2.00 \times 10^{5}$ & 5.3 \\
trifluralina & 0.1100 & $9.47 \times 10^{9}$ & $1.78 \times 10^{5}$ & 5.3 \\
\hline
\end{tabular}

\section{Conclusion}

The mathematical model presented in this paper is not based on experimental measures of pesticide contamination of surface or groundwater bodies, but on pesticide physical-chemical and ecotoxicological characteristics and water quality objective. The experimental assessment to information about pesticide leaching rates, doses applied, residues in water bodies, persistence in soil, toxicity effects in aquatic organisms, aquifer recharge rates and soil hydrological characteristics, will improve and refine the calculus of grey water volume of pesticides used in agriculture crops. The grey water volume can be determined through the pesticide physical-chemical characteristics, pesticide rates applied (dose), and the lowest EC50 value from the more susceptible aquatic organism. The model allows the estimate of grey water footprint of pesticide mixtures, a key component of the crop water footprint, considering the pesticide mixture toxicity effect in aquatic organisms and water quality. This water footprint component can be used as an indicator in agricultural sustainability or in formulation of governmental directives for the establishment of crop production sustainable systems that take into consideration appropriate patterns of water quality. We hope that this new method will contribute positively to the development of the water footprint and consequently to more sustainable use of freshwater resources. We believe that this water footprint component (model of grey water footprint for pesticide mixtures) can be used, with care and knowing it is not a panacea, as an indicator in agricultural sustainability or in formulation of governmental directives for the establishment of crop production sustainable systems that take into consideration appropriate patterns of water quality.

\section{Acknowledgements}

This project was funded by São Paulo Research Foundation or "Fundação de Amparo à Pesquisa do Estado de São Paulo" (Fapes) grant number 2010/06294-8, The Brazilian Agricultural Research Corporation or "Embrapa Empresa Brasileira de Pesquisa Agropecuária" (Embpapa) and Mrs Luiza Costa Mota Paraíba for her linguistic advice. 


\section{References}

[1] A. Hoekstra, "Globalization of water: sharing the planet's freshwater resources", Blackwell Publishing, Oxford, 2008.

[2] A. Hoekstra, "The water footprint assessment manual: Setting the global standard", Earthscan, Washington, 2011.

[3] A. Hornsby, "Pesticide properties in the environment", Springer-Verlag, New York, 1996.

[4] Allan, Fortunately there are substitutes for water otherwise our hydro-political futures would be impossible, em "Priorities for water resources allocation and management" (ODA, eds.) pp. 13-26, London, 1993.

[5] Allan, Overall perspectives on countries and regions, em "Water in the Arab World: Perspectives and Prognoses" (P. Rogers e P. Lydon, eds.) pp. 65-100, Harvard University Division Applied Science, Cambridge, 1994.

[6] Armas, The use of pesticides in sugar cane at the Corumbataí river basin and the risk of water pollution, Quim. Nova, vol. 28, pp. 975-982, (2005).

[7] Bliss, The toxicity of poisons applied jointly, Ann. Appl. Biol., vol. 26, pp. 585- 615, (1939).

[8] Chapagain, The water footprint of coffee and tea consumption in the Netherlands, Ecol. Econ., vol. 64, pp. 109-118, (2007).

[9] Chapagain, The blue, green and grey water footprint of rice from production and consumption perspectives, Ecol. Econ., vol. 70, pp. 749-758, (2011).

[10] Chapagain, The water footprint of cotton consumption: An assessment of the impact of worldwide consumption of cotton products on the water resources in the cotton producing countries, Ecol. Econ., vol. 60, pp. 186-203, (2006).

[11] CONAB, Acompanhamento de safra brasileira: cana-de-açúcar, terceiro levantamento, dezembro/2011, Brasília, 2012. $\quad$ Disponível em http://www.conab.gov.br/OlalaCMS/uploads/arquivos/12_12_12_10_34_43_boletim_cana_port ugues_12_2012.pdf [Acessado em fevereiro de 2013].

[12] Di Guardo, Simulation of pesticide runoff at Rosemaund Farm (UK) using the SoilFug model. Sci. Pollut. Res., vol. 1, pp. 151-160, (1994).

[13] Finizio, Assessing the environmental risk of pesticide mixtures in water bodies: the case of the Luria basin (Lombardia Region, Italy), pp. 667-676, Proceedings of the XII Symposium Pesticide Chemistry, Piacenza, 2003.

[14] Finizio, Predicting pesticide mixtures load in surface waters from a given crop. Agric. Ecosyst. Environ., vol. 111, pp. 111-118, (2005).

[15] Hoekstra, Virtual water trade: A quantification of virtual water flows between nations in relation to international crop trade, Value of Water Research Report Series No. 11, UNESCOIHE, Delf, 2002. Disponível em http://www.waterfootprint.org/Reports/Report11.pdf [Acessado em fevereiro de 2013]. 
[16] Loewe, The problem of synergism and antagonism of combined drugs, ArzneimittelForsch, vol. 3, pp. 285-290, (1953).

[17] Mekonnen, A global and high-resolution assessment of the green, blue and grey water footprint of wheat, Hydrol. Earth Syst. Sci., vol. 14, pp. 1259-1276, (2010).

[18] Page, Fresh tomato production for the Sydney market: an evaluation of options to reduce freshwater scarcity from agricultural water use, Agr. Water Manage, vol. 100, pp. 18-24, (2011).

[19] Paraiba, Soil temperature effect in calculating attenuation and retardation factors, Chemosphere, vol. 48, pp. 905-912, (2012).

[20] Rao, Indexes for ranking the potential for pesticide contamination of groundwater, Soil Crop Sci. Soc.,vol. 44, pp. 1-8, (1985).

[21] Ridoutt, The water footprint of food waste: case study of fresh mango in Australia, J. Clean Prod., vol. 18, pp. 1714-1721, (2010).

[22] Ridoutt, Water footprint of livestock: comparison of six geographically defined beef production systems, Int J. Life Cycle Assess., vol. 17, pp. 165-175, (2012).

[23] Salmoral, The water footprint of olives and olive oil in Spain, Span J. Agric. Res., vol. 9, pp. 1089-1104, (2011).

[24] Verro, Predicting pesticide environmental risk in intensive agricultural areas. I: screening level risk assessment of individual chemicals in surface waters, Environ. Sci. Technol., vol. 43, pp. 522-529, (2009).

[25] Wendland, Water balance in the Guarani Aquifer outcrop zone based on hydrogeologic monitoring, J. Hydrol., vol. 342, pp. 261-269, (2007).

[26] W. Jury, “Soil Physics”, John Wiley \& Sons, New York, 1992. 